\section{EMBRYRIDDLE}

Aeronautical University

SCHOLARLY COMMONS
Journal of Aviation/Aerospace

Education \& Research

Volume 2

Number 1 JAAER Fall 1991

Article 13

Fall 1991

\title{
The Aviation Education Teacher Resource Center: A Unique \\ Strategy to Improve Math and Science Education
}

Gerald D. Gibb

Patricia Fleener-Ryan

Follow this and additional works at: https://commons.erau.edu/jaaer

\section{Scholarly Commons Citation}

Gibb, G. D., \& Fleener-Ryan, P. (1991). The Aviation Education Teacher Resource Center: A Unique Strategy to Improve Math and Science Education. Journal of Aviation/Aerospace Education \& Research, 2(1).

https://doi.org/10.15394/jaaer.1991.1061

This Article is brought to you for free and open access by the Journals at Scholarly Commons. It has been accepted for inclusion in Journal of Aviation/Aerospace Education \& Research by an authorized administrator of Scholarly Commons. For more information, please contact commons@erau.edu. 


\title{
THE AVIATION EDUCATION TEACHER RESOURCE CENTER: A UNIQUE STRATEGY TO IMPROVE MATH AND SCIENCE EDUCATION
}

\author{
Gerald D. Gibb and Patricia Fleener-Ryan
}

\begin{abstract}
A unique program that enhances the applied mathematics and science knowledge of teachers was established at Embry Riddle Aeronautical University (ERAU). The program provides materials, equipment, education, and curriculum development services to educators at no cost. This model of collaboration between a university and a school district is presented as a template to enhance staff development efforts in other districts. Although this program presents a specific orientation of interest unique to the collaborating institutions, it clearly demonstrates how resources can be acquired and assembled by capitalizing on the strengths of the participants.
\end{abstract}

\section{INTRODUCTION}

Staff development programs are often relied upon to improve the quality and skills of educators and consequently to enhance the educational curriculum. Recent studies (Thompson and Cooley, 1987; Cooley and Thompson, 1986) of staff development programs across the nation indicate that those programs with the strongest legislative, district, and fiscal support are those most likely to be recognized as exemplary. This is particularly true in the Southern region of the country where staff development programs are typically mandated by law. It should come as no surprise that programs receiving the greatest effort and attention are those that are designated as outstanding. The effort described here is a unique collaboration between a school district and a University that resulted in an innovative program to increase staff development resources. The paper describes how a district staff development program is strengthened, without using district or state resources, by establishing a University based Teacher Resource Center. The Teacher Resource Center focuses on developing aviation education and awareness of teachers by providing aviation curriculum guides, computer software, audio-visual instructional materials, workshops, site visits of aviation facilities, aviation career presentations, youth academies, aviation instructional kits, demonstration devices, computers, and a wealth of classroom materials.

The program was developed to enhance educator knowledge and awareness in applied mathematics and science. Unlike in-service education, institutes, and workshops, this program was designed to be a permanent resource available within the local school districts. In this respect, the disadvantages of short term, fixed time programs could be averted. Fixed time programs (those programs which do not have a continuous followon) are often criticized for: (a) Covering too much material in limited time, (b) poor scheduling, (c) inaccessibility to a supply of classroom materials, (d) rigid structuring, and (e) being a one time event with little follow-on (Boschee \& Heim, 1980). The program set out in this paper is fully established, operates year round, and is available to educators in both public and private institutions.

This paper addresses the history, goals, and resources assembled; the advantages to teachers having access to these facilities; and the ways school district needs are being met. The purpose of this paper is to demonstrate how the strengths of an aviation institution of higher education can be capitalized upon to strengthen the staff development efforts within a school district. Consequently, specific recommendations for developing similar staff development resources are offered.

PROGRAM ORIGINS

The program was initiated on the recognition that mathematics, science, and engineering education is declining in the United States and that Embry Riddle Aeronautical University 
could contribute to improving interest in these academic fields by motivating teachers and students through the excitement of aviation. The underlying philosophy is that aviation can provide a medium to stimulate interests by offering concrete applications of the natural sciences and engineering.

The tremendous diversity of backgrounds of the faculty, in conjunction with numerous resources that could be adapted to the elementary/secondary education level, was utilized to build the foundation. The program was originally instituted because several faculty had the personal materials and resources and a strong desire to promote aviation education at the precollege level.

The Teacher Resource Center began in 1987 as a result of several independent and unrelated initiatives. Foremost was the establishment of the Model School Program by the State of Florida Department of Education. The Model School Program was begun by the state to develop innovative approaches to teaching.

Model schools function to test and evaluate new technologies for other schools statewide. Only five campuses in the state hold the designation Model School. Mainland High School, adjacent to the University, is one of the five schools selected. Embry Riddle Aeronautical University is a formal partner in this endeavor.

Secondly, the Federal Aviation Administration began seeking organizations that were willing to serve as Aviation Education Teacher Resource Centers. The Centers would be responsible for organizing and distributing curriculum materials suitable for secondary and elementary school levels. The University agreed to provide this service and was officially designated a Teacher Resource Center in June, 1987.

Finally, the University and the school district enjoy a long term relationship. University faculty often participate as classroom guest speakers for the schools; serve as judges for science, math, and engineering fairs; and serve on Teacher Education Center Councils for the district. The University is a convenient and exciting field trip for school groups. These activities are possible because many University faculty are deeply committed to enhancing student motivation and interest in the sciences, mathematics, and engineering fields at the precollege level.

ERAU recognized that it had, or could obtain, the unique resources needed to strengthen the staff development programs in the district.

Analyses of the annual districtwide needs assessment process indicated a strong need for additional support in the mathematics, sciences, and computer science disciplines.

The Teacher Resource Center was established as the facility to collect and house the materials necessary to provide that support, and from its early beginnings as a repository of Federal Aviation Administration materials, it has grown into an extensive resource of aerospace, earth and space science, and aviation materials for $\mathrm{K}-12$ teachers.

\section{PROGRAM GOALS}

The mission of the Center is to provide strong staff development support in the areas of math, science, and computer science without using district resources. The Center was not founded solely to introduce aviation education into the curriculum. Staff development support is accomplished by providing teachers with additional knowledge in a technical area, assistance with the development of specific lesson plans, and the materials to effectively implement the lesson plan in the classroom.

Knowledge is provided by individualized instruction at the Center or brief readings in specific topic areas. Topic areas are generally chosen to represent the application of a concept that is already taught in the curriculum. The development of the lesson plan is structured to teach a concept in depth and often includes class activities, demonstrations, media presentations, and class experiments. The focus of lesson plan development is to present concepts in concrete, observable terms. Substantial emphasis is given to classroom activities that involve the students as active participants. The lesson plans draw upon the equipment and material resources housed at the Center for effective implementation. This approach assures that current teaching techniques are enhanced while effectively integrating the new strategies into the current curriculum.

\section{PROGRAM RESOURCES}

\section{AND UNIQUE FEATURES}

The Center encompasses a broad range of multi-media materials and curriculum guides. The vast majority of these materials were obtained as contributions from numerous 
government agencies and private corporations. In particular, the National Aeronautics and Space Administration, the Federal Aviation Administration, Beechcraft Corporation, Cessna Inc., Pepsi Corporation, State Departments of Transportation, General Aviation Manufacturers Association, the Civil Air Patrol, and several aerospace related corporations donated materials through their public relations departments. Printed teaching aids through these organizations included curriculum guides; experiments for secondary and elementary levels; classroom and role playing activities; bulletin board posters; various worksheets, readings, and exercises; and field trip suggestions. Many organizations also provide reproducible video tapes, slides, overhead masters, and computer software without cost for educational use. These materials were augmented by audio-visual aids purchased by a charitable grant from a private agency.

The Center is also equipped with: (a) IBM and Apple computers, (b) a laminating machine, (c) photocopiers, (d) a slide duplicator, (e) video cassette recorder/players and monitors, and $(f)$ slide and film projectors. Whenever practical the equipment is lent to individual teachers or schools. All equipment was either donated or acquired through a charitable grant. Most state departments of education, local charities, and local corporations offer small grants aimed at improving the educational system within their geographic areas.

The Center is also a gateway for teachers to numerous other resources. Arrangements to tour and observe aircraft flight lines, air traffic control towers and centers, simulation facilities, and meteorology laboratories are all handled by the Center and These experiences are made available to both teachers and students. The meteorology laboratory at ERAU offers an unmatched resource for Earth and Space Science secondary teachers. The laboratory accesses real-time and archived weather data for the entire western hemisphere. A typical use for this facility is to provide teachers with a video recorded history of a specific weather event. Hurricane development and storm formation are concepts easily displayed in high school classrooms using materials produced in this laboratory. The laboratory is also well equipped to produce color slides of weather phenomena and a wide range of printed weather charts. Teachers receive handson experience with the state-ofthe-art techniques and laboratory equipment available.

Each year the Center also coordinates an excursion to the National Congress on Aviation Education. The Congress provides a forum for sharing new concepts and strategies for classroom teaching. Transportation is provided to teachers at no cost, using a military airlift.

The purpose of assembling such an extensive collection of resources was to provide teachers in this district with the means to strengthen curricula. Recognizing that most teachers had limited exposure to the aerospace/aviation sciences, a staff was provided to assist in lesson planning. The Center is staffed with a professional instructional specialist and graduate student assistant. Strong staffing support was necessary to assist teachers in determining which resources could be assembled or developed to meet a specific teaching objective. The staff is further augmented by participating university faculty representing mathematics, physics, computer science, engineering, and aeronautical science. This unique combination of extraordinary educational materials and subject matter expertise results in the development of innovative teaching strategies.

\section{PROGRAM ADVANTAGES}

\section{AND BENEFITS}

In the past two years, even though the program is still in its infancy, over 130 teachers and student teachers and more than 600 students have visited the Center. In the summer of 1990, 40 teachers attended two workshops sponsored by this program. The first two-week workshop focused on Earth and Space Science, while the second workshop emphasized using aerospace/aviation as a vehicle to teach math, science, and engineering concepts.

The program offers a significant contribution to elementary and secondary education by:

- providing teachers exposure to a field of knowledge otherwise not accessible to them;

- offering a large amount of educational materials and equipment to enhance the curriculum;

- improving staff development opportunities on an individual basis and/or through group experiences in workshops; 
- providing laboratories and facilities to afford teachers hands-on opportunities;

- expanding school district resources without commensurate increases in district financial obligations;

- establishing a link, through a collaborative effort, between pre- and post- secondary teachers;

- providing students with an environment conducive to witnessing math, science, and engineering principles as they are applied to aerospace/aviation.

The Center serves a large geographic area, and teachers who agree to participate are placed in contact with teachers in other schools who have similar curriculum objectives. This option provides a useful network among teachers to share experiences and new strategies.

\section{PROGRAM \\ EFFECTIVENESS}

The effectiveness of the Teacher Resource Center can be seen in a variety of applications throughout the local school districts. Teachers who have participated in the aviation workshops have uniformly exhibited at least an $80 \%$ gain in aviation knowledge and have qualified for mandatory state teacher certification points.

More important, however, is the qualitative measure of program success. In the past two years, classroom tours of aviation/aerospace facilities, student aviation youth academies and programs, and aviation/ aerospace exhibits at local re- gional science and engineering fairs, have increased dramatically.

Utilization records also indicate a considerable increase in incorporating aviation materials into the classroom environment. Requests to the Teacher Resource Center have accelerated state wide for services, presentations, materials, site visits, workshops, and summer youth programs. This expansion required a full time, professional coordinator to direct the program.

Further program effectiveness research plans include tracking standardized mathematics and science test scores in schools extensively involved in the program. During 1991 the effectiveness of youth summer workshops on high school retention rates for "at risk" students will also be investigated.

\section{RECOMMENDATIONS}

The importance of this program lies in the model it presents rather than in the specific disciplines that are represented. This program is successful because it capitalizes on the strengths of a university while fulfilling the needs of a school district. That model of collaboration can be adapted by other districts to enhance staff development efforts (a strong aviation/ aerospace background is not necessary) using resources that are available in their areas.

Specifically, the following generic template will prove useful in establishing a similar program:

- determine the current and future needs of the school district, assessing the most critical staff de- velopment requirements (ie. computer science, mathematics, physical science, laboratory training, media production, etc.);

- assess the strengths of the universities and colleges in the local area, focusing particularly on the unique characteristics, laboratories, and facilities at those institutions;

- determine initially what college faculty are interested in collaborative efforts with the school district. This can be accomplished by identifying faculty who participate in local science fairs and/or who sponsor advanced standing/advanced placement students. Research oriented faculty may also participate by assessing the impact of an innovative staff development program on student performance;

- identify and contact government, corporate, and educational organizations that can contribute materials to your effort. Most organizations have career related information and materials available;

- determine the government and private grants available with an interest in your program's emphasis. Federal and state sources are obvious. There are numerous independent organizations in each geographic area seeking to 
fund innovative educational approaches;

- seek support from local businesses and social groups. (Private enterprise is a valuable source of equipment, supplies, and guest speakers);

- build the program care fully, ensuring that the resources are organized, that they contribute to classroom instruction, and that they support professional development.

The success of a collaborative effort such as this relies upon determining how the expertise base and resources of a college can be focused to meet the needs of the local school district. University faculty can provide a substantial increase in staff development opportunities and materials appropriate to the precollege classroom.

This program provides an example of how to develop such a resource apart from the programs established within traditional departments of education at teacher training colleges.

Gerald D. Gibb earned his doctorate in Psychology from Brigham Young University, and is currently an Aviation Psychologist and Director of the Airway Science Simulation Laboratory at Embry Riddle Aeronautical University, Daytona Beach, FL campus. Dr. Gibb has published and presented over fifty papers.

Patricia Fleener-Ryan, Director and Coordinator of the Federal Aviation Administration (FAA) Aviation Education Teacher Resource Center at Embry Riddle Aeronautical University, earned a Masters of Arts degree in Instructional Technology and a Bachelors of Science in Elementary Education. She won the 1990 FAA Southern Region and the National Aviation Education Individual Champion Award. She has conducted workshops, institutes, and youth programs. Ms. Ryan also serves as an Educational Specialist for the Civil Air Patrol.

\section{REFERENCES}

Boschee, F. \& Hein, D.D. (1980). How effective is inservice education? Phi Delta Kappan, 61 , 427.

Cooley, V.E. \& Thompson, J.C. (1968). School improvement and state staff development programs: A national research survey. Educational Research Quarterly, 10, 2-3.

Thompson, J.C. \& Cooley, V.E. (1987). Staff development in local school districts: Findings from quality programs in the fifty states. Educational Research Quarterly, 11, 2-7. 